NBER WORKING PAPER SERIES

\title{
DOMESTIC TAX POLICY AND THE FOREIGN SECTOR: THE IMPORTANCE OF ALTERNATIVE FOREIGN SECTOR FORMULATIONS TO RESULTS FROM A GENERAL EQUILIBRIUM TAX ANALYSIS MODEL
}

Lawrence H. Goulder

John B. Shoven

John Whalley

Working Paper No. 919

NATIONAL BUREAU OF ECONOMIC RESEARCH 1050 Massachusetts Avenue Cambridge MA 02138

June 1982

Paper presented at the NBER Tax Simulation Conference, Palm Beach, Florida, January 26-27, 1981. The research reported in this paper was supported by the Office of Tax Analysis, U.S. Treasury Department. We are very grateful to Charles Ballard of Stanford University for outstanding research assistance. The research reported here is part of the NBER's research program in Taxation. Any opinions expressed are those of the authors and not those of the National Bureau of Economic Research. 


\section{Abstract}

DOMESTIC TAX POLICY AND THE FOREIGN SECTOR:

THE IMPORTANCE OF ALTERNATIVE FOREIGN SECTOR FORMULATIONS

TO RESULTS FROM A GENERAL EQUILIBRIUM TAX ANALYSIS MODEL

There is a growing recognition among public finance economists of the inappropriateness of closed economy models for analyzing alternative U.S. tax policies. In response to this, this paper reports on four different external sector specifications for the Fullerton-Shoven-Whalley general equilibrium tax model of the U.S. The alternative formulations permit an assessment of their impact on model findings and provide the enhanced capability for analysis of tax policies which connect closely with foreign trade issues (such as a VAT).

Results indicate that the different external sector formulations can substantially affect the model's findings. When the model permits international capital flows, the effect of a tax policy can be quite different from what a closed economy model would predict. Capital mobility substantially increases the efficiency gain implied by corporate tax integration, while it more than eliminates the efficiency advantage of moving from an income tax to a consumption tax (unless adjustments are made in the foreign tax credit). The sensitivity of the efficiency evaluation of domestic tax policies to the functioning of international capital markets suggests the need for further research to determine precisely how those markets operate.

Lawrence H. Goulder Department of Economics Stanford University Stanford, CA. 94305
Professor John B. Shoven Department of Economics Stanford University Stanford, CA. 94305 (415) 497-3273
Professor John Whalley Department of Economics University of Western Ontario London, Ontario, Canada N6A 5C2

(519) 679-3973 


\section{Introduction}

There is a growing recognition among public finance economists of the inappropriateness of closed economy models for analyzing alternative U.S. tax policies. Foreign trade has increased fairly sharply as a fraction of GNP in the last twenty years, and capital markets have become more international in scope. United States investors participate in foreign capital markets both directly and indirectly through multinational corporations, and foreign direct investment in the U.S. has grown enormously in the past ten years. In this paper, we report on some alternative treatments of the external sector within an empirical general equilibrium model of the United States economy and tax system. This general equilibrium model has been described elsewhere [Fullerton, Shoven, and Whalley (1978); Fullerton, King, Shoven, and Whalley (1978)]. The new specifications of the external sector are motivated by the twin concerns of developing a general equilibrium analysis of tax policy where foreign trade issues enter, and of assessing the sensitivity of earlier results concerning alternative domestic tax policies to the specification of the external sector.

In previous analyses employing this general equilibrium model, we have given little emphasis to foreign trade. The external or foreign sector was modelled quite simply, and relatively little attention was given to how the foreign sector might influence the U.S. economy. One simplifying assumption employed in previous versions of the model was that for each commodity, the value of net trades between the U.S. and the rest of the world remained unchanged as prices changed. This assumption provided us with a convenient 
way of closing the model, but was difficult to reconcile with utility maximization. Our alternative specifications are somewhat more complex, but more plausible.

The first alternative which we explore is the use of constant elasticity excess demand functions (a constant elasticity offer curve in the two good case) to describe foreigners' merchandise trade behavior. We also consider a variant of this formulation in which certain imports are treated as imperfect rather than perfect substitutes for comparable domestic products. For both of these formulations, we consider several different elasticity parameters to evaluate model sensitivity. We then present two formulations which model capital mobility between the U.S. and the rest of the world. The first of these formulations introduces flows of capital services between the U.S. and abroad which depend on the difference between U.S. and foreign rental rates. An elasticity parameter controls the sensitivity of capital service flows to differences in rental rates. The second of these formulations is similar, but involves capital goods rather than capital services. These last two formulations permit us to model the U.S. as a taker of the rental prices of foreign capital. We were motivated to introduce these formulations partly by the belief that treating the U.S. in this way might significantly affect the model's evaluation of alternative tax policies.

In order to evaluate the sensitivity of the model to these different specifications, we analyze the integration of corporate and personal income taxes [Fullerton, King, Shoven, and Whalley (1979)] and the elimination of savings distortions in the U.S. income tax [Fullerton, Shoven, and Whalley (1980)] under each of these alternative formulations. We also consider the 
effects of adopting alternative forms of value-added tax (VAT) in the U.S. We consider VAT's of both the income and consumption type, and on both destination and origin bases.

The plan of the paper is as follows. We first outline the structure of the basic tax model before any of the modifications we describe are incorporated. Then we present our alternative foreign sector formulations and discuss the linkage between foreign trade issues and tax policy design. A final section of the paper presents results and major findings.

II. Main Characteristics of the FullertonShoven-Whalley General Equilibrium Tax Model ${ }^{1}$

The Fullerton-Shoven-Whalley general equilibrium tax model of the U.S. can be regarded as a higher dimensional extension of traditional Edgeworth box analysis, with particular functions and parameter values used to represent preferences and production possibilities. Taxes enter as ad valorem distortions of factor use, production decisions, and consumer purchases. The model generates sequences of equilibria through time. The equilibria are connected through savings decisions which imply different augmentations to the capital service endowment passed between periods. The model is calibrated to 1973 benchmark data assumed to lie on a balanced growth path for the economy.

The production side of the model includes 19 profit-maximizing industries which use labor and capital according to constant elasticity of substitution (CES) or Cobb-Douglas production functions. Substitution elasticities are chosen for each industry as the central figures in Caddy's (1976) survey of the literature and range from 0.6 to one. We use data from the Survey of Current Business and unpublished data from the Commerce Department's National Income

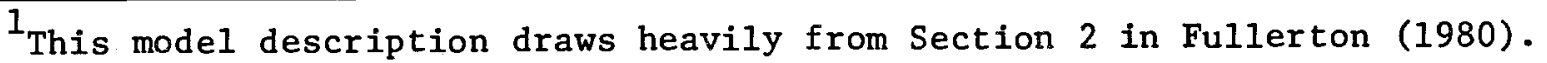


Division to obtain each industry's payments for labor and capital. ${ }^{1}$ Base year quantities are derived according to the convention that a unit of each primary factor is that amount which earns one dollar net of taxes in the 1973 benchmark year. A fixed coefficient input-output matrix is derived from Bureau of Economic Analysis tables.

The ad valorem tax on each industry's use of capital comprises the corporation income tax, state corporate franchise taxes, and local property taxes. The Social Security tax and contributions to workmen's compensation are modelled as an ad valorem tax on industry use of labor. Various federal excise taxes and indirect business taxes are modelled as output taxes; a different tax rate applies to each of the 19 industries. State and local sales taxes apply to each of the 15 consumer goods in the model.

The 19 producer goods can be used directly by government, for export, or for investment. These producer goods can also be translated into the 15 consumer goods which enter consumer demand functions. This translation is made possible by a fixed-coefficient " $G$ " matrix." The G matrix is necessary because the Commerce Department production side data include industries such as mining, electrical manufacturing, and trade, while the Labor Department's Survey of Consumer Expenditures provides data on purchases of goods like furniture, appliances, and recreation.

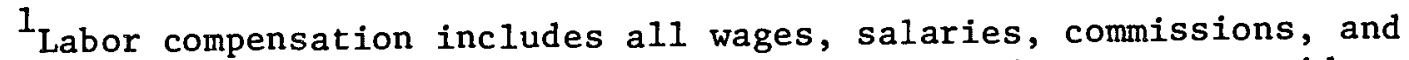
tips, while capital earnings include net interest paid, net rent paid, and corporate profits with capital consumption adjustments and inventory valuation adjustments. Non-corporate profits were divided between labor and capital on the basis of full-time-equivalent hours and average wage for each industry. Some industries were averaged over several years to avoid recording transitory effects.

2 The $G$ matrix derives from data in the February 1974 Survey of Current Business. 
Industry and government payments to buy labor and capital services are exactly matched by total household receipts from the supply of each factor. The Treasury Department's Merged Tax File provides information on labor and capital income for each of our 12 consumer classes, as well as tax payments and an estimate of the average marginal income tax rate, $\tau_{j}$, for each group. These range from a one percent average marginal rate for the first income class to a 40 percent rate for the highest income class. A progressive income tax system is then modelled as a series of linear schedules, one for each group. Pensions, IRA plans, and Keogh plans are modelled as a 30 percent saving subsidy to capture the proportion of saving that now has such tax-sheltered treatment.

We also model a "personal factor tax," a construct designed to capture discrimination among industries by the personal income tax. Each industry is assigned a fraction, $f_{i}$, representing the proportion of capital income from industry $i$ which is fully taxable at the personal level. This fraction is determined from proportions of capital income paid as non-corporate income, dividends, capital gains, interest, and rent. ${ }^{1}$ Taxable capital income is subject to $\tau$, the overall capital-weighted average marginal personal income tax rate. At the consumer level, rebates are given to groups with a $\tau_{j}$ less than $\tau$, while additional tax is collected from others. The personal factor tax acts as a withholding tax at the industry level, and corrections at the consumer level sum to zero. The model thus captures the favorable tax treatment

${ }^{1}$ All dividends are 96 percent taxable, because of the four percent that fell under the $\$ 100$ exclusion in 1973 . All retained earnings are 73 percent taxable. This results from the value tax deferral and rate advantages for capital gains, as well as the taxation of purely nominal gains. Interest and rents are fully taxable except for the imputed net rent of owner-occupied homes, while the non-corporate investment tax credit also appears as a personal tax reduction varying by industry. 
given to industries with noncorporate investment tax credit, and to the housing industry.

The expanded income of each consumer group is given by transfer income plus capital and labor endowments. ${ }^{1}$ The latter is defined as $7 / 4$ of labor income. The figure $7 / 4$ results from our estimate that in the benchmark, 40 hours are worked out of a possible 70 hours. Consumer demands are based on budget-constrained maximization of the nested CES utility function:

$$
U=U\left[H\left[\sum_{i=1}^{15} x_{i}^{\lambda}, \ell\right], C_{f}\right] .
$$

In the first stage, consumers save some income for future consumption, $\mathrm{C}_{\mathrm{f}}$, and allocate the rest to a subutility function, $H$, over present consumption goods, $\mathrm{X}_{i}$, and leisure, $\ell$. The elasticity of substitution between $\mathrm{C}_{\mathrm{f}}$ and $\mathrm{H}$ is based on Boskin's (1978) estimate of 0.4 for the elasticity of saving with respect to the net-of-tax rate of return. Saving in the model derives from consumer demands for future consumption under the expectation that all present prices, including the price of capital, will prevail in all future periods. Then income for $\mathrm{H}$ is divided between the purchase of leisure, $\ell$, and the purchase of a bundle of 15 consumer goods. The composition of the consumer good bundle derives from the maximization of a Cobb-Douglas function. The elasticity of substitution between leisure and consumer goods is based on an estimate of 0.15 for the elasticity of labor supply with respect to the net-of-tax wage.

Consumer decisions regarding factor supplies are thus made jointly with consumption decisions. Demands for leisure and for saving will depend on all

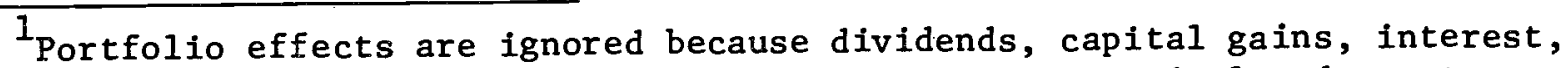
rent, and other capital income types are summed to obtain capital endowments. 
relative prices, whether for factor endowments or for commodity purchases. Saving is converted immediately into investment demand for producer goods, with proportions based on national accounting data for fixed private investment and inventories.

In previous versions of the model, the foreign trade sector has been modelled such that the net value of exports less imports is constant for each producer good. This simple treatment closed the model, maintained zero trade balance, and allowed easy calculation of trade quantities, given prices. As we shall see in the next section, however, this specification was hard to reconcile with traditional trade theory; hence the alternative external sector formulations.

The specification of the government sector completes the model. Revenues from the various taxes described above are used for transfers, labor, capital, and producer goods. Lump-sum transfers to each consumer group are based on Treasury Department data for social security, welfare, government retirement, food stamps, and similar programs. Government demands for factors and commodities are represented by a Linear Expenditure System derived from a Stone-Geary utility function. In equilibrium the government budget is balanced.

Because the benchmark data required for this model are so comprehensive, the sources are necessarily divergent. The two sides of a single account are often collected by different agencies with different procedures, and thus do not match. In order to use all of these data together, there must be adjustments to ensure that each part is consistent with the rest. To do this we accept some data as superior and other data are adjusted to match. All industry and government uses of factors are taken to be fixed, so consumers' factor incomes and expenditures must be scaled. Tax receipts, transfers, and government endowments are 
fixed, so government expenditures must be scaled to balance their budget. Similar adjustments ensure that supply equals demand for all goods and factors. 1

The fully consistent data set then represents a benchmark equilibrium, where values are separated into prices and quantities by assuming that a physical unit of each good and factor is the amount that sells for one dollar. Certain elasticity parameters are imposed exogenously, and the model's equilibrium conditions are used to generate remaining behavioral equation parameters which are consistent with the data set. Factor employments by industry are used to derive production function weights, and household expenditures are used to derive utility function and demand function weights. We can use the resulting tax rates, function parameters and endowments to solve the model, perfectly replicating the benchmark equilibrium. This calibration allows for a test of the solution procedure and ensures that the various agents' behaviors are mutually consistent in our benchmark data set.

We use the Merrill (1971) variant of Scarf's (1973) algorithm to solve in each period for a competitive equilibrium in which profits are zero and supply equals demand for each good or factor. Simplex dimensions are required only for labor, capital, and government revenue, since a knowledge of these three "prices" is sufficient to evaluate all agent behavior. Producer good prices are calculated based on factor prices and the zero-profits condition, while consumer good prices derive from producer good prices through the G transition matrix. A complete set of prices, quantities, incomes, and allocations

${ }^{1}$ In particular, the input-output matrix does not conform to the requirement that gross output of each good can be measured by the column sum plus value added, or the row sum plus final demand. An iterative row and column scaling method is employed to generate a consistent matrix, and similar scaling satisfies similar conditions for the expenditure matrix. 
is calculated for every equilibrium. Since it is not based on differential calculus, the computational model can accommodate discrete changes in any tax or distortion, without linearity assumptions and without ignoring income effects. There can be any number of sectors and agents, and any specifications of demand, so long as Walras' Law holds.

The dynamic sequencing of single period equilibria in the model first assumes that the 1973 consistent data set or benchmark equilibrium lies on a steady-state growth path. Observed saving behavior and the capital endowment are translated into an annual growth rate for capital (approximately 2.75 percent), and this growth is also attributed to effective labor units. This exogenous growth rate for labor is split evenly between population growth and Harrod-neutral technical progress. The benchmark sequence of equilibria is then calculated by maintaining all tax rates and preferences, increasing labor exogenously, and allowing saving to augment capital endowments over time. ${ }^{1}$ By construction, this sequence will have constant factor ratios and constant prices all equal to one.

Policy change simulations are performed by altering tax rates while retaining preference parameters and the exogenous labor growth rate. Savings and other behavior then conform to the specified elasticities, growth of capital diverges from the steady state rate, and the economy begins to approach a new steady-state path with a new capital/labor ratio. Sequences are compared by discounting the " $\mathrm{H}$ " composites of instantaneous consumption through time with appropriate terminal conditions. Only leisure and present consumption are

${ }^{1}$ We convert a dollar of saving into capital service rental units through multiplication by $\gamma$, the real after-tax rate of return. The model assumes that 25 dollars of saving can purchase a capital asset that will earn one dollar per period net of depreciation and taxes. That is, a value of .04 is used for $\gamma$. 
included in this welfare measure because saving is reflected in later consumption of the sequence. The sequence is discounted at a four percent rate and includes only the initial population. Otherwise, the importance of future periods would be sensitive to population growth.

The welfare gain or loss of a tax change is the aggregate compensating variation, defined as the number of dollars at new prices that would be required for each consumer to attain the old sequence of consumption values. The model thus incorporates both interindustry and intertemporal tax distortions and efficiency changes.

\section{Different External Sector Formulations}

In this section we outline alternative ways of modelling external sector behavior in the general equilibrium tax model of the U.S. In the next section we explore the sensitivity of results from various policy simulations to the external sector specifications.

\section{A. The Existing Foreign Sector Specification}

The external sector modelling currently used in the U.S. general equilibrium tax model focuses solely on commodity trade and ignores all capital transactions. Exports and imports are classified into three categories of producer goods: those for which there are net imports ( 7 commodities); those for which there are net exports ( 7 commodities); and those which are not traded ( 5 commodities). The benchmark data set for 1973 is adjusted to guarantee that the value of total exports equals the value of total imports. The model then assumes that the value of net exports remains constant for each export commodity and the value of net imports remains constant for those commodities which are imported. For each of the import commodities, we have 
(III.1)

$$
P_{i} M_{i}=M_{i}^{0}
$$

and for the export commodities, we have

$$
\text { (III.2) } \quad P_{j} E_{j}=E_{j}^{O} \text {, }
$$

where $M_{i}^{o}$ and $E_{j}^{o}$ are the benchmark net import and export quantities, respectively. Recall that the benchmark prices are unity, by the units assumptions. $P_{i}, M_{i}, P_{j}, E_{j}$ are the current prices and quantities for imports and exports. Since initially,

$$
\sum_{j} E_{j}^{o}=\sum_{i} M_{i}^{O}
$$

we always have the condition that

$$
\sum P_{j} E_{j}=\Sigma P_{i} M_{i}
$$

or the value of exports equals the value of imports. This trade balance condition is necessary in a general equilibrium model which does not allow for international capital flows.

This modelling has several drawbacks. First, commodities cannot switch between being imported and being exported. Far more serious is the feature that import supply by foreigners reacts perversely to changes in commodity prices: this specification has import supplies negatively related to prices with an elasticity of -1 .

A related problem with this treatment is that in the two good analog it implies an offer curve which is different from those usually found in traditional trade theory. This difficulty is transparent if we plot, for the 
two good case, the foreign offer curve which the U.S. economy is assumed to face. Suppose $E$ and $M$ each now refer to scalars rather than vectors; the constant value net trade formulation implies

(III.5) $\quad \mathrm{E}=\mathrm{E}_{\mathrm{O}} \cdot \mathrm{P}_{\mathrm{E}}^{-1}$

(III.6) $\quad \mathrm{M}=\mathrm{M}_{0} \cdot \mathrm{P}_{\mathrm{M}}^{-1}$

where $E_{0}$ and $M_{0}$ are base year exports and imports, and $P_{E}, P_{M}$ are export and import prices, respectively.

In this simple formulation we can choose $E$ to be the numeraire and set $P_{E}=1$. The implied foreign offer curve is then:

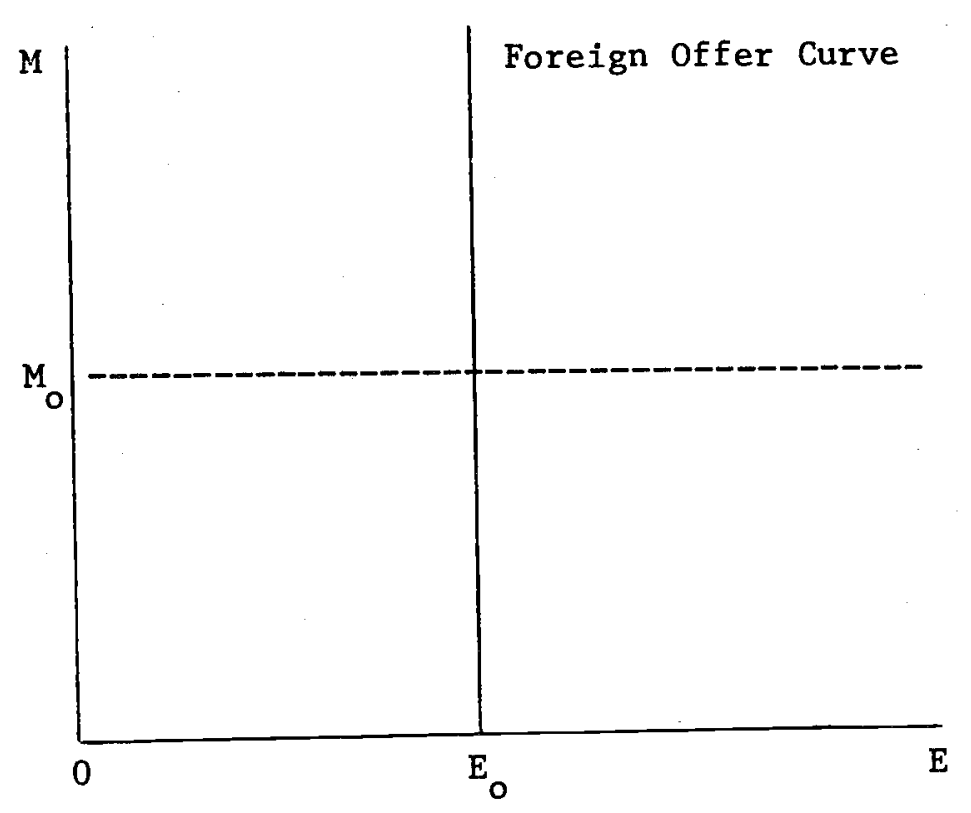

Figure III.1. Diagram of Foreign Offer Curve

When superimposed on a diagram incorporating the usual form of home country offer curve this is seen to violate traditional trade theory on two counts: (a) the foreign offer curve does not go through the origin; and (b) the foreign offer curve is concave rather than convex to the $M$ axis. 


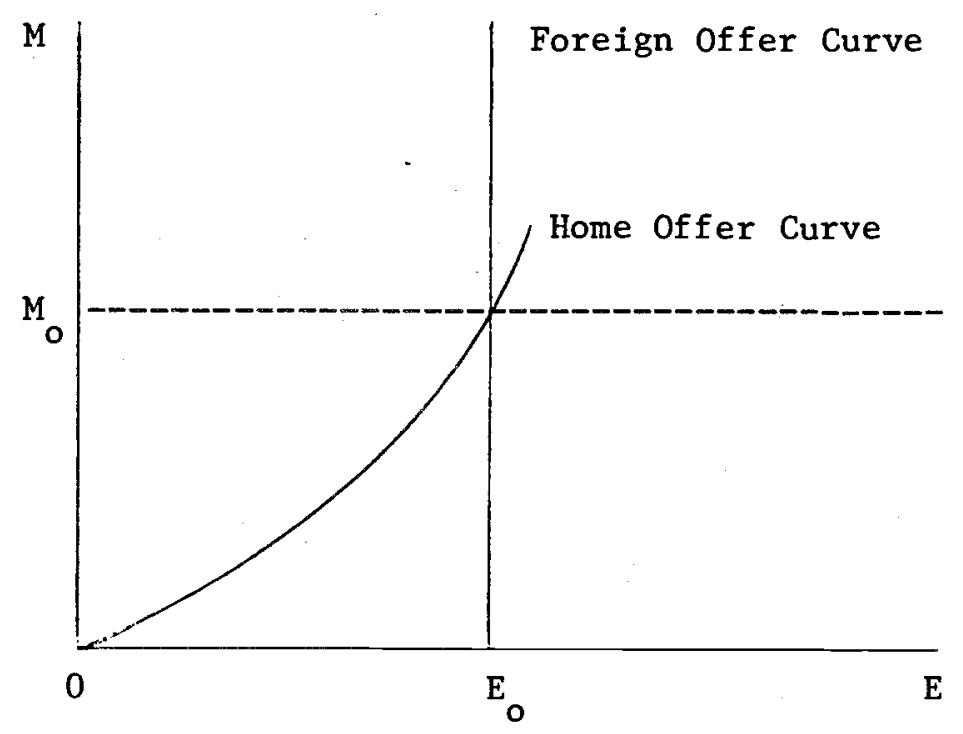

Diagram III.2. Diagram of Foreign Offer Curve with Superimposition of Traditional Home Offer Curve

Clearly this simple formulation contains some major departures from traditional trade theory; consequently, we consider a number of alternative external sector formulations.

\section{B. General Constant Elasticity Specification ${ }^{1}$}

The first alternative specification differs from the simple specification above in two main ways. First, import supply functions are modelled so as to have a positive price elasticity. Second, the restrictive Cobb-Douglas type assumption of the previous specification--the assumption that the value of net exports remains constant for each commodity--is no longer employed.

In this formulation, the relative prices of traded goods are endogenously determined in the model. Trade balance is assured since foreigners' excess demand functions (export demand and import supply) satisfy budget balance.

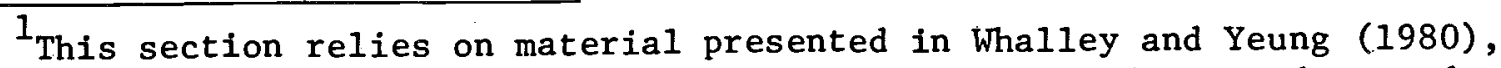
which analyzes the external sector equation system discussed in Boadway and Treddenick (1978). 
This specification operates as follows. For each of the $n$ producer goods (in the case of our model, $n=19$ ), we specify an import supply function and an export demand function, with parameters $\mu$ and $n$ as price elasticities of import supply and export demand, respectively:

(III. 7)

$$
M_{i}=M_{i}^{o}\left(\frac{{ }_{M_{i}}}{e}\right)^{\mu} \quad 0<\mu<\infty
$$

$$
E_{i}=E_{i}^{o}\left(\frac{P_{i}}{e}\right)^{n} \quad \begin{aligned}
& i=1, \ldots, n \\
& -\infty<n< \\
& i=1, \ldots, n
\end{aligned}
$$

where $\mathrm{P}_{\mathrm{M}_{i}}$ is the domestic price of imports and $\mathrm{P}_{E_{i}}$ is the domestic price of U.S. exports (cost-covering price received by U.S. producers). The variable e can be interpreted as an exchange rate between domestic and foreign prices although we will show below how e can be removed by a simple substitution into the trade balance equation. As in all classical general equilibrium models which focus solely on relative goods prices, this exchange rate is a purely financial magnitude with no significance for real behavior in longrun equilibrium, although it is helpful for our exposition if we use this terminology. ${ }^{1} \frac{P_{M}}{e}$ is the price the foreign exporter receives and $\frac{{ }_{E_{i}}}{e}$ is the price that foreign purchasers must pay for U.S. exports. The sign restrictions on $\mu$ and $\eta$ are discussed below.

In order to close the system and solve the general equilibrium model, we add the trade balance constraint that

\footnotetext{
${ }^{1}$ No well-defined financial sectors are specified in our model; there is no domestic or foreign demand-for-money function which determines the relative prices of domestic and foreign monies (the exchange rate) in a purely monetary sense.
} 
(III.8)

$$
\sum_{i=1}^{n} P_{M_{i}} M_{i}=\sum_{i=1}^{n} P_{E_{i}} E_{i}
$$

If we substitute for $M_{i}$ and $E_{i}$ from equation (III.7), we have

$$
\sum_{i=1}^{n} P_{M_{i}} M_{i}^{0}\left(\frac{P_{i}}{e}\right)^{\mu}=\sum_{i=1}^{n} P_{E_{i}} E_{i}^{o}\left(\frac{E_{i}}{e}\right)^{n} \text {. }
$$

If we now define

$$
\alpha_{1}=\sum_{i=1}^{n}\left(P_{M_{i}}\right)^{\mu+1} M_{i}^{o}
$$

(III. 10)

$$
\alpha_{2}=\sum_{i=1}^{n}\left(P_{E_{i}}\right)^{n+1} E_{i}^{o}
$$

equation (III.9) can be solved for the exchange rate parameter

(III.11) $\quad e=\left(\frac{\alpha_{2}}{\alpha_{1}}\right)^{\frac{\mu}{n-\mu}}$.

Finally, substituting this result in (III.7) gives

$$
M_{i}=M_{i}^{o} P_{i}\left(\frac{\alpha_{2}}{\alpha_{1}}\right)^{\frac{\mu}{\mu-n}}
$$

(III.13) $\quad E_{i}=E_{i}^{\circ} P_{i}\left(\frac{\alpha_{2}}{\alpha_{1}}\right)^{\frac{\eta}{\mu-\eta}}$.

Note that $\alpha_{1}$ and $\alpha_{2}$ are themselves functions of import and export prices, respectively. Equations (III.12) and (III.13) can be thought of as reduced form import supply and export demand equations. Another interpretation is 
that they are the external sector behavior equations compensated for zero trade balance. They reflect the fact that one cannot simply specify an import supply elasticity and an export demand elasticity, and simultaneously assume zero trade balance. The trade balance condition provides a cross equation restriction implicit in our solution procedure for equations (III.12) and (III.13).

Another thing to note about the reduced form import supply and export demand equations is that they depend only on domestic prices: the exchange rate has been eliminated by substitution. Thus, equations (III.12) and (III.13) depend only upon the real terms of trade given by the $\left(\frac{\alpha_{2}}{\alpha_{1}}\right)$ term. In the case where only two commodities are involved, the equation system (III.7) specifies an offer curve of constant elasticity which describes the excess demand functions for the foreign sector. The elasticity of the offer curve is

$$
\varepsilon^{o c}=\frac{\eta}{1+\eta} \cdot \frac{1+\mu}{\mu}
$$

and this parameter $\varepsilon^{o c}$ is related to the price elasticity of both foreign export demand and foreign import supply through the equation [see Johnson (1961), Ch. II, Appendix]:

$$
\varepsilon^{\text {oc }}=\frac{\varepsilon_{E}^{F D}}{\varepsilon_{E}^{F D}-1}=\frac{\varepsilon_{M}^{F S}+1}{\varepsilon}
$$

where $\varepsilon_{E}^{F D}$ and $\varepsilon_{M}^{F S}$ define the foreign price elasticities of export demand and import supply.

This implies that in terms of the reduced form equations characterizing the system, 
(III.16)

$$
\varepsilon_{E}^{F D}=\frac{\eta(1+\mu)}{(\mu-\eta)}
$$

which for $\eta \leq-1, \mu>0$ implies $\varepsilon_{E}^{F D} \leq 0$. Also,

$$
\varepsilon_{M}^{F S}=\frac{-\mu(1+n)}{(\mu-n)}
$$

and for $\mu \geq 0, \eta \leq-1, \varepsilon_{M}^{F S}>0$.

These elasticities imply that the true price elasticities of the system of foreign excess demand functions are not in fact given by $\eta$ and $\mu$ as the equations (III.7) might seem to suggest, but by the more complicated forms described above. Furthermore, $\mu$ and $\eta$ are not independent parameters but jointly imply an elasticity for the offer surfaces we use. To have the appropriate sign for the value of $\varepsilon_{M}^{F S}$, $\eta$ must be less than -1 , rather than simply negative as stated above.

Because of the form properties of this system, we describe this specification of the external sector as one where the U.S. is a taker of a foreign offer surface (satisfying a foreign economy version of Walras' Law) of constant elasticity form. The form of utility functions necessary to generate such surfaces is discussed more fully in Johnson (1954, 1961) and Gorman (1957). In the section where we present our results, we discuss further our choice of $\mu$ and $n$.

When we analyze trade in homogeneous products, it is natural to assume that a country will not import and export the same good. This assumption can be expressed as

(III.18)

$$
E_{i}^{o} \cdot M_{i}^{o}=0 \quad i=1, \ldots, n
$$


However, the assumption is violated by much empirical data: there are a number of commodities which are both exported and imported by the U.S. This phenomenon of "cross hauling" is evident from trade statistics, even with finely aggregated data, and underlies much of the recent literature on intra-industry trade [see Grubel and Lloyd (1975) and the subsequent literature].

There are many reasons for this phenomenon. In some cases, cross hauling is dictated by explicitly non-competitive behavior, such as that mandated by the U.S.-Canada automobile manufacturing agreement. However, it is also possible to reconcile cross hauling with competitive behavior. One explanation asserts that foreign commodities are qualitatively different from domestic goods. This assumption of qualitative difference by country (e.g., U.S. and foreign cars being treated as close but not perfect substitutes) is referred to as the "Armington assumption," following Armington (1969, 1970). Cross hauling can also be explained by reference to geography and transportation costs. For example, it may be perfectly sensible for the U.S. to export Alaskan oil to Japan and at the same time import the identical product through ports on the east coast and the Gulf of Mexico, given the cost of delivering Alaskan oil to the east.

Previous versions of the model dealt only with net trade flows, as if trade occurred only in one direction for each commodity and there were no cross hauling. In each of the new formulations, it is possible to deal only with net trades, as before, or alternatively to allow for cross hauling. When cross hauling is specified, it is necessary to substitute gross trade flows for net trade flows in the export demand and import supply equations. (For example, $E_{i}^{O}$ and $M_{i}^{O}$ would represent gross magnitudes in the base year in the previous equations in this section.) Although our formulations can incorporate cross hauling, the reasons for the cross hauling are not explicitly provided by the model. 


\section{Trade Modelling with Imperfectly \\ Substitutable Imports}

Our second external sector specification separates imports into two broad categories, depending on whether they are perfect or imperfect substitutes in production for domestically produced intermediate goods. We treat all of the imports discussed in previous subsections as perfect substitutes in production for U.S. producer goods. We then represent these imports as a negative component of final demand; as a consequence, every additional unit of import of producer good $i$ reduces the gross output requirement of industry $i$ in the model. Industries demanding intermediate goods from industry $i$ are assumed to be indifferent as to whether those goods are produced at home or imported.

We now consider a model specification which allows some imports to be imperfect substitutes for domestic goods in production. Under this specification, we introduce a single new aggregated import commodity which enters the production structure as an imperfectly substitutable input. 1 This specification invokes the Armington assumption, since it assumes that there is a qualitative difference between the imported input and any domestic inputs used in production [Armington (1969)].

The foreign excess demand equations are now

$$
\begin{aligned}
M_{i}=M_{i}^{0}\left(\frac{P_{M_{i}}}{e}\right)^{\mu} & 0<\mu<\infty \\
E_{i}=E_{i}^{0}\left(\frac{P_{i}}{e}\right)^{n} & -\infty<n<-1 \\
& i=1, \ldots, n
\end{aligned}
$$

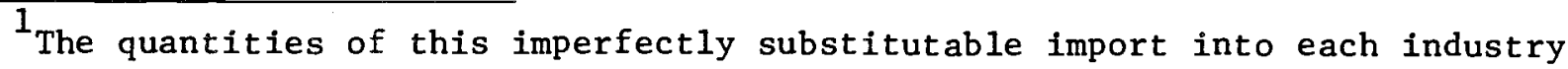
were based on rows $80 \mathrm{~A}$ and $80 \mathrm{~B}$ of the $1971 \mathrm{U}$.S. input-output matrix published by the Bureau of Economic Analysis of the Department of Commerce. 
and

(III. 21)

$$
R=R^{\circ}\left(\frac{P_{R}}{e}\right)
$$

$0<\mu<\infty$

where (III.21) is the supply function for the import commodity ("resources") which enters the production structure. This commodity is different from all domestically available goods. The demand for imported resources is a derived demand based on production requirements (as with the other factors of production, labor and capital). $M_{i}^{0}$ and $E_{i}^{0}$ may represent either gross or net magnitudes as desired.

The trade balance condition is now

(III.22)

$$
P_{R} R+\sum_{i=1}^{n} P_{M_{i}} M_{i}=\sum_{i=1}^{n} P_{E_{i}} E_{i}
$$

Let

$$
\gamma_{1}=R^{0}\left(P_{R}\right)^{\mu+1}+\sum_{i=1}^{n}\left(P_{M_{i}}\right)^{\mu+1} M_{i}^{0}
$$

and

$$
\gamma_{2}=\sum_{i=1}^{n}\left(P_{E_{i}}\right)^{n+1} E_{i}^{o} .
$$

Then, substituting (III.19), (III.20), and (III.21) into (III.22), and using the above notation, we get

$$
e=\left(\frac{\gamma_{2}}{\gamma_{1}}\right)^{\frac{1}{n-\mu}}
$$

and

(III.26)

$$
\begin{aligned}
& M_{i}=M_{i}^{o} P_{M_{i}}^{\mu}\left(\frac{\gamma_{2}}{\gamma_{1}}\right)^{\frac{n}{\mu-n}} \\
& E_{i}=E_{i}^{o} P_{E_{i}}^{\eta}\left(\frac{\gamma_{2}}{\gamma_{1}}\right)^{\frac{\mu}{\mu-n}}
\end{aligned}
$$


(III.28)

$$
R=R^{\circ} P_{R}^{\mu}\left(\frac{\gamma_{2}}{\gamma_{1}}\right)^{\frac{\mu}{\mu-\eta}}
$$

As in the previous section, these are the reduced form or (trade balance) compensated import supply and export demand equations. They provide a constant elasticity set of excess demand functions to describe foreign behavior.

With this formulation, the production structure has also been modified to incorporate the imported resource. In the previous version of the model, the production function for each sector could be written as

$$
Q_{j}=\min \left[\frac{1}{a_{o j}} \operatorname{VA}\left(K_{j}, L_{j}\right), \frac{x_{1 j}}{a_{1 j}}, \ldots, \frac{x_{n j}}{a_{n j}}\right]
$$

where the $a_{i j}(i=1, \ldots, n)$ are the fixed per unit intermediate input requirements, $x_{i j}$ are the available intermediate inputs, $V A(\cdot, \cdot)$ is a CES value added function with capital $\left(K_{j}\right)$ and labor $\left(L_{j}\right)$ as inputs, and $a_{o j}$ is the requirement of value added per unit of output.

Under this new specification, the production function is

$$
Q_{j}=\min \left\{\frac{I}{a_{0 j}} J\left[\operatorname{VA}\left(K_{j}, L_{j}\right), R\right], \frac{x_{1 j}}{a_{1 j}}, \ldots, \frac{x_{n j}}{a_{n j}}\right\}
$$

where $J$ is a CES or Cobb-Douglas function for each sector, and a now represents the requirements of the resource/value added composite per unit of output. A critical parameter in this formulation is the value chosen for the elasticity of substitution between $R$ and $V A\left(K_{j}, L_{j}\right)$ for each sector. We denote these elasticities by $\sigma_{\mathrm{VA}}^{\mathrm{R}}$. We will return to the choice of values for $\sigma_{\mathrm{VA}}^{\mathrm{R}}$. 
The solution procedure takes advantage of the separability of the production structure, as in the original Fullerton-Shoven-Whalley model. Each producer first calculates the optimal factor proportions to use in his value added function, given the minimum factor costs of production. From this information, the optimal combination of domestic factor value added and imported resources can be determined by minimizing the per unit cost of the $\mathrm{J}$ function. From this solution, we can compute all domestic producer prices using the Samuelson non-substitution theorem. These prices can be used to determine the government's demand for producer products, the foreign demand for producer goods (exports), and the supply of both producer good imports and resource imports. The producer good prices determine consumer goods prices, while the factor prices and the government revenue determine consumer incomes. Consumer demands are evaluated, and the derived demands for producer goods necessary to meet consumer demand for consumption and investment goods are computed. With these components, we can obtain the demand for domestically supplied producer goods, from which the derived demand for labor, capital, and imported resources is determined. Further, from all the transactions in the model, government tax receipts can be calculated. The excess demand for labor, capital, resources, and government revenue is then computed, and the model proceeds as in earlier versions, until an equilibrium set of prices and tax revenue is found where all markets clear.

This specification presents two additional data requirements. We use a modified version of the $1970 \mathrm{U} . \mathrm{S}$. I/O Table underlying our 1973 benchmark data, to spearately identify a row of factor imports by industry in our I/O data. We also need to specify a substitution elasticity between U.S. value added and R. For these, we use estimates of the aggregate import price elasticity of 
import demand for the U.S. In the central case we take the value [from Stern et al (1977)] of 1.7 to represent the pure substitution effect between domestic value added and imported resources, and take $0.5,1.0$, and 3.0 as sensitivity cases.

\section{A Simple Modelling of International Capital Flows}

To this point, our model formulations have not accounted for international capital flows. From a modelling perspective, however, it is very important whether a single international capital market or separate national capital market is considered, since this choice may significantly affect the perceived impact of a tax change. In this subsection, we present a simple formulation of international capital flows, which allows foreign rental rates on capital to affect rental rates in the U.S.

Here we add one consumer to the model--a "foreigner" who is endowed with large quantities of those commodities which the U.S. imports or exports, and with a large amount of capital services. In the benchmark year, the foreigner's endowment of each import or export commodity is usually set at 5 times the benchmark level of imports of that commodity by the U.S., while the foretgner's capital services endowment is five times the U.S. capital services endowment in the benchmark. As part of a sensitivity analysis we have varied the magnitudes of the foreigner's endowments of goods and capital services. The foreigner "consumes" most of his endowments; that is, most of these import goods and capital services are used by the foreign economy rather than sold or rented to the U.S. In the benchmark, in particular, the foreigner sells just the observed amount of import commodities (a fifth of his endowment) to the U.S. economy, and purchases the observed quantity of export commodities (also a fifth of his endowment) from the U.S. The foreigner rents no capital services to the U.S. in the benchmark; he thus consumes 
his entire endowment of capital services. A loose interpretation would be that these capital services are foreign resources which provide directly consumable output to the foreigner.

As U.S. prices change with a tax change, however, the foreigner alters his behavior. If the U.S. rental price of capital increases above the foreign rental price (exogenously fixed in real terms), the foreigner will "rent" some of his endownent to be used in U.S. production (i.e., there will be a capital inflow from the perspective of the U.S.). On the other hand, should the U.S. rental price of capital fall below the foreign rental price, the foreigner may "rent" U.S. capital for his foreign consumption (i.e., a capital outflow from the U.S. perspective).

This behavior is specified as

$$
W_{K}-X_{K}=W_{K} \cdot\left(P_{K} / P_{K F}\right)^{E_{K}}
$$

where $W_{K}$ is the capital service endowment of the foreigner, $X_{K}$ are capital services rented to the U.S. by the foreigner (or rented from the U.S. if $X_{K}$ is negative), and $E_{K}$ is an elasticity parameter controlling capital flow responses in the model. $P_{K}$ and $P_{K F}$ are the rental rates of capital in the U.S. and abroad, respectively. Since $P_{K}=P_{K F}=1$ in the benchmark, the benchmark value of $\mathrm{X}_{\mathrm{K}}$ is zero.

The critical parameters in this formulation are the ratio of $W_{K}$ to the U.S. capital service endowment (5 in our central case analysis) and $E_{K^{\prime}} E_{K}$ should be negative to give the capital service flow responses we require. In our central case $E_{K}$ is -1.0 . For sensitivity analysis, we use values for $\mathrm{E}_{\mathrm{K}}$ ranging from zero to -10.0 .

Equation (III.31) thus determines capital service flows in the model, once factor prices are known. A two stage procedure is thus involved in 
determining foreign behavior. We first determine $X_{K}$, and from this we calculate income remaining to be spent on all other goods. For simplicity, the expenditure on other goods follows a Cobb-Douglas specification, with weights determined from benchmark data. A point worth noting is that equation (III.31) is not explicitly derived from utility maximizing behavior of the foreigner. We focus on welfare evaluations for the U.S. only, and treat our model of the foreign sector as a model closure system which satisfies external sector balance and has the qualitative properties we desire.

Our motivation for this formulation incorporating capital service flows relates to the recent debate between Feldstein (1980) and Harberger (1980), about the degree to which the U.S. operates in a relatively competitive world capital market. Feldstein, observing a high correlation between the savings of countries and their investment, argues that there are severe restrictions on the operation of a world capital market. Harberger asserts that this correlation is not so large and that this statistic is not sufficient evidence for concluding the malfunctioning of the world capital market.

This issue is important because of its implications for policy evaluation from general equilibrium tax models. In a world with a perfect, frictionless international capital market, the domestic choice between an income and consumption tax would not affect the aggregate employment of capital in the U.S. Despite the fact that an income tax discourages saving by U.S. consumers, and thus tends to discourage capital formation, the rest of the world would provide U.S. industry with capital until its rate of return was equal to the world level. However, an origin-based tax such as the U.S. corporation income tax would still be distortionary, affecting both the amount of capital in the economy and its 
allocation across industrial sectors. In their most recent exchange, Feldstein and Harberger seemed to be converging to the view that, while there is some pressure towards equalizing the rates of return to capital across world markets, this equilibrium is incomplete, and even the partial movements observed take substantial amounts of time. We can capture the key aspects of this debate by altering $E_{K}$, the elasticity parameter for the demand for capital services by foreigners.

\section{E. An Extension of the Capital Flows Modelling}

The previous subsection has the rest of the world endowed with a large amount of capital services which it "rents" to the U.S. if the U.S. offers a higher rental price. If the rental price in the U.S. falls, the foreigner rents capital from the U.S. While this is a step toward including world capital markets in our model, it fails to capture important aspects of foreign investment. Under this specification, a capital inflow involves a financial outflow (the U.S. must make the rental payments). In fact, the principal response to high U.S. rates of return is more likely to be direct foreign investment in the U.S., rather than the rental to the U.S. of foreignowned capital. The rest of the world would purchase U.S. capital goods, providing an immediate financial inflow. Foreigners would then accumulate a claim on the future earnings of their acquired capital rather than receive immediate financial compensation.

This behavior can be incorporated in our model using a somewhat different representation of the "foreigner." The initial U.S. capital endowment of the foreigner is taken as zero. The foreigner, however, can acquire U.S. capital by purchasing the savings good (the 16th consumer good, which is a fixed proportion 
portfolio of real investment goods). He will do this if the expected rate of return on U.S. investments rises above the expected rate of return on foreign investments. This will generate a capital and monetary flow. He is interested in the rate of return net of the corporation income tax, the corporation franchise tax, and property taxes. Should the U.S. rate of return fall relative to the foreign rate, he may sell foreign capital to domestic savers. Once again, we do not model the production structure of the rest of the world; rather, the foreigner simply "consumes" foreign capital as in the previous subsection.

This formulation is reasonably complex in terms of modeliling. There now are two kinds of capital goods, foreign and domestic, offering separate (although conceivably identical) rates of return. Initially, domestic consumers own only domestic capital and the foreigner owns only foreign capital. The demand functions are structured such that the foreigners will save in the U.S. only if the U.S. rate of return rises above the foreign rate, whereas the U.S. consumers will purchase foreign capital service endowments only if the U.S. rate of return falls below the foreign rate. While the U.S. rate of return is endogenous in the model, the foreign rate is usually set at the benchmark rate, although it can be influenced by certain tax policies of the U.S. ${ }^{1}$

Savings behavior in the U.S. stems from the same demand functions as in the Fullerton-Shoven-Whalley model, except that it involves not just a domestic savings good but a composite savings good aggregated over domestic and foreign savings goods. For each household,

${ }^{1}$ For example, in this model the foreign rate of return would be affected by a U.S. policy which changes the percentage of U.S. consumers' savings which can be deducted from taxable income. Such a policy alters the after-tax price of savings to U.S. consumers, whether the savings is at home or abroad. Consequently, the policy affects the foreign rate of return to U.S. consumers of saving abroad. 
(III.32)

$$
\begin{aligned}
& S^{D}=B S \\
& S^{F}=(1-B) S
\end{aligned}
$$

where $S$ is total savings, and $S^{D}$ and $S^{F}$ are domestic and foreign savings goods acquired. $\beta$ is a distribution parameter which depends on the relation between domestic and foreign rates of return $\left(r^{F}, r^{U S}\right)$.

$$
\begin{array}{ll}
B=1 & \text { if } r^{U S} \geq r^{F} \\
B=e^{-z_{1}\left(r^{F}-r^{U S}\right)} & \text { if } r^{U S}<r^{F}
\end{array}
$$

Here $r^{F}$ and $r^{U S}$ are expected rates of return to U.S. consumers. Because of differences in marginal tax rates, $r^{F}$ and $r^{U S}$ each will differ across the 12 household classes distinguished by the model. We account for these differences in the model, although for convenience we speak of a single $\mathrm{r}^{\mathrm{F}}$ and $\mathrm{r}^{\mathrm{US}}$ in this discussion.

In the benchmark $\mathrm{r}^{F}=\mathrm{r}^{\mathrm{US}}=1$ and $\beta=1$ (U.S. households buy no foreign capital goods). In the solution of the model, $\beta$ for each household is used to form a composite price for savings goods which enters household budget constraints. Household utility functions only have an interpretation over composite goods, since we do not investigate real characteristics of assets (such as risk) which would account for a diversified portfolio by savers. We set $z_{1}$, the elasticity parameter in equation (III.33), at 250 in our central case. We consider this figure to be roughly comparable to the $E_{K}$ value of -1.0 in the previous specification.

The foreigner's savings in the U.S., $\mathrm{S}_{\mathrm{US}}^{\mathrm{F}}$, are given by 


$$
\begin{aligned}
& \text { (III.34) } \quad S_{U S}^{F}=0 \quad \text { if } r_{F}^{U S} \leq r_{F}^{F} \\
& S_{U S}^{F}=Z_{2}\left(r_{F}^{U S}-r_{F}^{F}\right)^{Z_{3}} \quad \text { if } r_{F}^{U S}>r_{F}^{F}
\end{aligned}
$$

Here $r_{F}^{U S}$ and $r_{F}^{F}$ are U.S. and foreign rates of return expected by the foreigner. Because U.S. consumers and foreigners are not treated identically in the tax system, $r^{U S}$ generally differs from $r_{F}^{U S}$, and $r^{F}$ from $r_{F}^{F}$.

A two stage procedure similar to that in subsection $D$ applies here. First, we determine the foreigner's investment behavior abroad, with remaining expenditures allocated in a Cobb-Douglas fashion. In our central case analysis, we take $z_{2}$ to equal 50,000 and $z_{3}$ to equal 0.5 . In this specification, our dynamic sequencing of equilibria takes account of previous investments abroad in determining capital service endowments in each country in each period. Investments abroad in a given period imply international capital service flows in subsequent periods.

In the following section, we investigate how the model's findings are affected by the four formulations we have just described.

IV. Policy Analyses under Alternative

Externa1 Sector Formulations

In this section we examine results from a number of policy analyses, using the various formulations of external sector behavior presented in the preceding section. We consider the introduction of an 80 percent savings deduction in the U.S, income tax [as considered by Fullerton-Shoven-Whalley (1980)]. We also consider corporate tax integration in the U.S. [as considered by Fullerton-King-Shoven-Whalley (1980)], and the introduction of alternative forms of value-added tax in the U.S. 
We use the same dynamic sequence of equilibria approach used in the earlier papers by Fullerton et al, and compute sequences of equilibria linked through household savings decisions, as described earlier. In the base case, the economy is assumed to lie on a balance growth path. Under different policies, the economy is initially displaced from balanced growth, and asymptotically returns to a new balanced growth path with a different ratio of capital service to labor endowment in each period. Our welfare analysis of gain or loss to the economy involves a calculation of the Hicksian compensating variation in each period for each household group. We first discount into present value terms, using the real net of return to capital as the discount rate, and then we sum over households.

Our analyses involve the same numerical specification used by Fullerton et a1. We analyze six periods, each of ten-year duration, using the same values for all parameters which do not deal with the external sector. The various external sector formulations are incorporated as separate model extensions.

We refer to the four formulations as follows:

1. CONS ELAS NO ARM

2. CONS ELAS WITH ARM

\section{CAP SERV FLOW}

4. CAP GOOD FLOW
Foreigners' behavior involves constant elasticity demand functions (constant elasticity offer curve in two-good case); no Armington product heterogeneity enters; no capital service or capital good flows are considered

As in (1) except that we also consider Armington product heterogeneity for certain imported inputs

Flows of capital services take place between the U.S. and the rest of the world

Flows of capital goods take place between the U.S. and the rest of the world 
These formulations were described above in subsections III.B, III.C, III.D and III.E, respectively.

These formulations are listed in Table 1 along with the values we have specified for the more critical parameters. In the case of the first formulation, the parameters $\mu$ and $\eta$ imply an export price elasticity which the U.S. faces. We use an export price elasticity for the foreigner's demands of -1.4 . This is approximately the central case value reported in the recent compendium of Stern et al (1976). We use values for $\mu$ of 0.465 and $\eta$ of -10 . These jointly imply the -1.4 export price elasticity; the implied elasticity of the foreigner's import supply function is approximately 0.4 .

For sensitivity analyses in this case, we consider $\mu$ and $n$ set first at 10 and -10 and then at 1 and -1 . For the $10,-10$ case the export price elasticity is approximately -5 . In the two-good case, as $\eta$ and $\mu$ both become large (in absolute value), the elasticity of the offer curve approaches unity and this specification for the foreigner's behavior would imply that the U.S. is a sma11, open, price-taking economy. For the case of $1,-1$ the export price elasticity is -1 , and in the two-good case the elasticity of the offer curve is $\infty$. We also consider cases where net trade flows rather than the gross flows enter the benchmark calculation.

For the second formulation, the critical parameters are $\mu, n$, and $\sigma_{V A}^{R}$. We take the same $\mu$ and $n$ values as for the central case in our first formulation. $\sigma_{\mathrm{VA}}^{\mathrm{R}}$ is set a 1.7. In our sensitivity runs, $\sigma_{\mathrm{VA}}^{\mathrm{R}}$ is set at $0.5,1.0$ and 3.0 . For the capital service flow formulation, a critical parameter is $\mathrm{E}_{\mathrm{K}}$, which expresses the sensitivity of the foreigner's behavior to differences between the rental rates on capital employed in the U.S. and abroad. In our central case under this formulation, we set $E_{K}$ at -1.0 ; in sensitivity runs we consider values of $0,-0.1$, and -10.0 for $E_{K}$. 


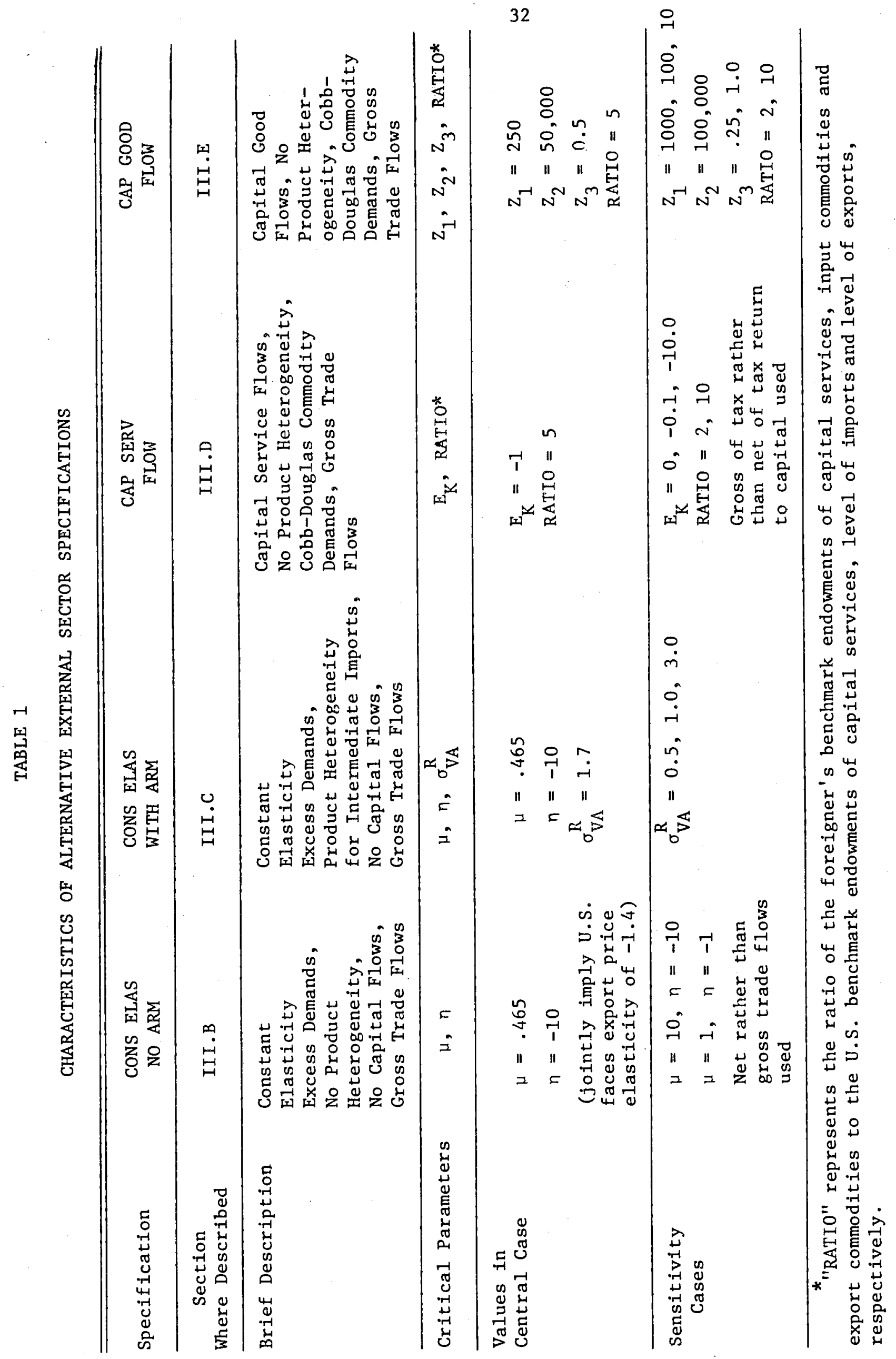


Another key parameter in this formulation is RATIO, the ratio of the foreigner's benchmark endowments of capital services, import commodities and export commodities to the U.S. endowment of capital services. level of imports and level of exports in the benchmark. RATIO is a rough indicator of the "size" of the rest of the world relative to the U.S. In our central case, we set RATIO equal to 5 ; in sensitivity runs we consider values of 2 and 10 for RATIO.

A final and important sensitivity analysis in this case involves the return to capital. In the central case, when foreigners rent to the U.S., they receive $P_{K}$, the real net of tax rental price of or return to capital. $\mathrm{P}_{\mathrm{KF}}$ is paid to the U.S. when Americans rent to foreigners. Because of the tax system in the U.S., a differential exists between the marginal product of capital (the gross of tax price) and the net of tax return to capital. Thus, the U.S. gains if it rents capital services from abroad, since the U.S. collects the marginal product of capital but pays the net of tax return to capital. Conversely, if the U.S. rents capital to the foreigner, the U.S. suffers a loss for the same reason. To correct for this, we calculate a tax rate which applies to international capital service transactions and use this new rate in one of our sensitivity cases.

For the capital good formulation, the critical parameters are $\mathrm{z}_{1}, \mathrm{z}_{2}$ and $\mathrm{z}_{3}$. These parameters determine the sensitivity of domestic households and of the foreigner to differences between domestic and foreign rates of return. We use values of 250 for $z_{1}, 50,000$ for $z_{2}$ and 0.5 for $z_{3}$ in our central case. In sensitivity cases we consider values of $1,000,100$ and 10 for $z_{1}, 100,000$ for $z_{2}$, and 0.25 and 1.0 for $z_{3}$. 


\section{A. Savings Deduction}

In Table 2 we show model results for a single tax policy--an 80 percent savings deduction--under the different external sector formulations. This policy, described in detail in Fullerton-Shoven-Whalley (1980), represents a move from the current income tax system toward an expenditure or consumption tax system. The deduction is only 80 percent since roughly 20 percent of savings is used for new housing construction which does not incur the "double" taxation of the income tax system. Thus an 80 percent deduction would closely approximate a full consumption tax system. We "additively" adjust marginal income tax rates (increasing or decreasing all rates by a certain number of percentage points) so that the total revenue raised by the government is not altered in any period by the policy change. We consider six equilibria spaced 10 years apart.

The original analysis suggests a present value gain to the U.S. of $\$ 538$ billion (1973 prices) from the tax change. It is useful to compare this number with the discounted present value of consumption plus leisure in the base sequence of $\$ 49$ trillion (1973 prices). The gain thus amounts to 1.10 of this discounted present value of the economy. Put another way, after allowing for the change in the timing of consumption, and spreading the gain involved over a number of years, an 80 percent savings deduction increases total consumer welfare by 1.10 percent per year.

The first two external sector formulations do not change this broad picture very much. In the constant elasticity case with no Armington good, the gain falls to $\$ 511$ billion. With the Armington good, the gain falls further to $\$ 479$ billion. This result indicates that the terms of trade effects of the tax change are weak, a finding which contrasts with the papers by Boadway and Treddenick (1978) and Whalley (1980); these studies find significant terms of 
trade effects associated with changes in factor taxes. These two papers both incorporate a complete Armington specification which leads to stronger terms of trade effects. In addition, in the present formulation there are not substantial differences in factor intensities of export and import competing industries, as a consequence, the offer surfaces for the U.S. have only limited bowness.

The major changes in results occur with the capital service and capital good flow formulations. In the service flow case, the $\$ 538$ billion gain

TABLE 2

FURTHER ANALYSIS OF 80 PERCENT SAVINGS DEDUCTION

IN U.S. INCOME TAX ${ }^{\mathrm{a}}$

(Dynamic welfare effects in present value of compensating variations over time)

\begin{tabular}{lc}
\hline \hline & Welfare Effect $^{\mathrm{b}}$ \\
\hline $\begin{array}{l}\text { 1. Original Fullerton-Shoven-Whalley } \\
\text { type formulation }\end{array}$ & $538(1.10)$ \\
2. CONS ELAS NO ARM (central case) & $511(1.04)$ \\
3. CONS ELAS WITH ARM (central case) & $479(0.98)$ \\
4. CAP SERV FLOW (central case) & $-476(-.97)$ \\
5. CAP GOOD FLOW (central case) & $-33 \quad(-.07)$ \\
\hline
\end{tabular}

${ }^{a}$ All results are from runs including six equilibria spaced ten years apart. An "additive" method of tax replacement (see page 34) was employed in every case.

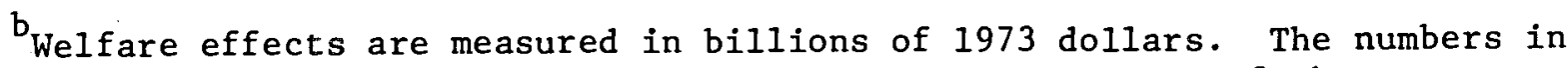
parentheses represent the welfare gain or loss as a percentage of the present discounted value of consumption plus leisure in the base sequence ( $\$ 49$ trillion). 
changes to a $\$ 476$ billion loss. The main reason for this has already been indicated above: the U.S. incurs substantial capital service outflows as a result of the policy change so that the U.S. foregoes the gross of tax return to capital (capital's marginal product), but only receives the net of tax return. In effect, the foreign tax authority gains at the expense of the U.S. Treasury, as a U.S. tax credit is given for foreign taxes paid. The cumulative capital service outflow in this case over 50 years is approximately $\$ 1.7$ trillion. In the sensitivity analysis, we note that the efficiency loss is reduced and even reversed as the $E_{K}$ parameter is reduced towards zero. An interesting policy prescription which some have suggested is that the U.S. either have additional taxes on capital income received from abroad or revoke the foreign tax credit. The additional tax rates, if used, would equal U.S. capital factor tax rates. This prescription ignores possible retaliatory consequences of such action. The capital good flow case reveals a similar result, although the effect is quantitatively weaker.

\section{B. Sensitivity Analysis}

In Table 3 we report our sensitivity analyses for our two constant elasticity formulations. Given that the central case results of these two forms do not differ significantly from each other or from those of the original specificiation, it may not be surprising that a similar conclusion applies for sensitivity cases. The choice of the $\mu$ and $n$ combination, or whether gross or net trade flows are specified, makes very little difference in the No Armington cases. In the Armington cases, the results are relatively robust with respect to changes in $\sigma_{V A}^{R}$. Gains fall from $\$ 487$ billion to $\$ 446$ billion as $\sigma_{V A}^{R}$ is lowered from 3.0 to 0.5 . 
TABLE 3

SENSITIVITY ANALYSIS OF 80 PERCENT SAVINGS DEDUCTION IN U.S. INCOME TAX FOR CONSTANT ELASTICITY FORMULATIONS

(Dynamic welfare effects in present value of compensating variations over time)

Welfare Effect

1. Original Formulation (Table 2, Case 1) 538

2. CONS ELAS NO ARM

Central Case $(\mu=.465 ; \eta=-10) \quad 511$

$\mu=10 ; \eta=-10 \quad 502$

$\mu=1 ; \eta=-1 \quad 538$

Net rather than gross trade flows 529

3. CONS ELAS WITH ARM
Central Case $\left(\mu=.465 ; \eta=-10 ; \sigma_{\mathrm{VA}}^{\mathrm{R}}=1.7\right)$

$\begin{array}{ll}\sigma_{\mathrm{VA}}^{\mathrm{R}}=0.5 & 446\end{array}$

$\sigma_{V A}^{R}=1.0$

$\begin{array}{ll}\sigma_{\mathrm{VA}}^{\mathrm{R}}=3.0 & 487\end{array}$ 
In Table 4 we report our sensitivity analysis of the 80 percent savings deduction cases from Table 2 for our capital service and capital good flow formulations. For the capital service flow formulation, a most dramatic result appears when the gross of tax rental price is employed instead of the net of tax price in international capital service transactions. In this case the large loss of $\$ 476$ billion in the central case changes to a gain of $\$ 562$ billion. This gain is even larger than in the cases without capital flows. The reason is that with a closed capital market the additional savings caused by the adoption of a consumption tax depresses the marginal product of capital more than with an international capital market. This demonstrates clearly the significance in the model of the U.S. instituting a compensatory tax on capital income received from abroad.

Sensitivity analysis for the capital service flow formulation also included changing $E_{K}$ from -1.0 to $0.0,-0.1$ and -10.0 and varying RATI0, the goods and service endowment ratio, between 2 and 10. As expected, the welfare loss is larger for higher absolute values of $E_{K^{*}}$ With $E_{K}=0$, we get results essentially equivalent to the formulations without capital flows.

For our capital good formulation we only report sensitivity on $\mathrm{Z}_{1}$ and the endowment ratio in Table 4 , because with an 80 percent savings case the U.S. saves abroad with no foreign savings in the U.S. ${ }^{1} z_{2}$ and $z_{3}$ are immaterial in this case but have an effect in the integration cases reported below, where the capital good flow is in the opposite direction. We thus report $z_{2}$ and $z_{3}$ sensitivity later. Table 4 reveals significant sensitivity to $Z_{1}$ values; there is relatively little sensitivity to the values for RATIO.

${ }^{1}$ For domestic consumers and more importantly for foreigners, this policy change lowers the U.S. rate of return relative to the foreign rate. Under these circumstances foreigners do not save in the U,S. (see sub-section III.E). 
TABLE 4

SENSITIVITY ANALYSIS OF 80 PERCENT SAVINGS DEDUCTION IN U.S. INCOME TAX FOR CAPITAL SERVICE AND CAPITAL GOOD FLOW FORMULATIONS

(Dynamic welfare effects in present value of compensating variations over time)

Welfare Effect

A. Capital Service Flow Formulation

1. Central Case (Table 2, Case 4)

$-476$

2. Gross of tax rental price used in place of net of tax price

3. $E_{\mathrm{K}}=0.0$ (changed from -1 )

4. $E_{K}=-0.1$ (changed from -1 )

5. $E_{Y}=-10,0$ (changed from -1 )

$-730$

6. RATIO $=2$ (changed from 5)

$-221$

7. RATIO $=10$ (changed from 5)

$-601$

B. Capital Good Flow Formulation

1. Central Case (Table 2, Case 5)

2. $z_{1}=1000$ (changed from 250)

3. $z_{1}=100$ (changed from 250) 122

4. $Z_{I}=10$ (changed from 250) 441

5. RATIO $=2$ (changed from 5) $-38$

6. RATIO $=10$ (changed from 5) $-26$ 


\section{Tax Integration}

In Table 5 we present further analyses of corporate and personal tax integration in the U.S. using the alternative external sector formulations presented earlier. Here we evaluate a policy of "full integration" as described in Fullerton, King, Shoven and Whalley (1980). Such a policy involves the elimination of the corporate income tax accompanied by increases in personal taxes on capital income. The corporate income tax is eliminated for both domestic- and foreign-owned firms situated in the U.S. Individuals are taxed on the basis of their total capital income, whether that income is realized (as dividends, rents, etc.) or accrues (e.g., as retained earnings).

As with Table 2, the two constant elasticity formulations do not make very much difference to results although gains increase rather than fall in comparison to the original. The capital service and capital good flow formulations, however, yield gains which are significantly higher than those under the original formulation. In these cases the gains are $\$ 1,031$ and $\$ 497$ billion, respectively, Tax integration induces a reallocation of capital from noncorporate to corporate sectors, since the latter experience a larger tax reduction from a policy of tax integration. This leads to an increase in the net-of-tax rental price of capital in the U.S.; the rental price and rate of return to capital rise in the U.S. relative to the rest of the world. Under the capital service flow formulation, this induces foreigners to rent their capital to the U.S., while in the capital good flow formulation, this leads to foreign saving in the U.S. In both cases, the U.S. experiences a substantial efficiency gain since it pays the net-of-tax return as its marginal product. We report sensitivity analyses on $z_{2}$ and $z_{3}$ for the capital good flow case; they have an impact in this situation as the foreigner saves in the U.S. (unlike the 80 percent savings deduction case). 
TABLE 5

FURTHER ANALYSIS OF U.S. CORPORATE AND PERSONAL TAX INTEGRATION ${ }^{a}$

(Dynamic welfare effects in present value of compensating variations over time)

\begin{tabular}{lc}
\hline \hline & Welfare Effect ${ }^{\mathrm{b}}$ \\
\hline 1. Original Formulation & $265(.54)$ \\
2. CONS ELAS NO ARM (Central Case) & $287(.59)$ \\
3. CONS ELAS WITH ARM (Central Case) & $321(.66)$ \\
4. CAP SERV FLOW (Central Case) & $1,031(2.10)$ \\
5. CAP GOOD FLOW (Central Case) & $497(1.01)$ \\
6. CAP GOOD FLOW (Sensitivity Cases) & $666(1.36)$ \\
$\mathrm{z}_{2}=100,000$ (changed from 50,000) & $927(1.89)$ \\
$\mathrm{z}_{3}=.25$ (changed from 0.5$)$ & $326(.67)$ \\
$\mathrm{Z}_{3}=1.0$ (changed from 0.5$)$ &
\end{tabular}

${ }^{a}$ All results are from runs involving six equilibria spaced ten years apart. An "additive" method of tax replacement (see page 34) was employed in every case.

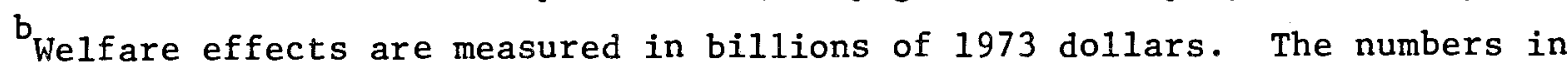
parentheses represent the welfare gain or loss as a percentage of the present discounted value of consumption plus leisure in the base sequence ( $\$ 49$ trillion).

\section{Value-Added Tax}

In Table 6 we present results from our simulations of introducing four alternative forms of value-added tax in the U.S. Much of the recent discussion of value-added taxation in the U.S. has been prompted by the VAT systems introduced in Europe over the last 15-20 years. The destination based VAT in Europe 
TABLE 6

WELFARE IMPACTS OF INTRODUCING 10 PERCENT VAT OF DIFFERING TYPES ${ }^{a}$

(Dynamic welfare effects in present value of compensating variations over time)

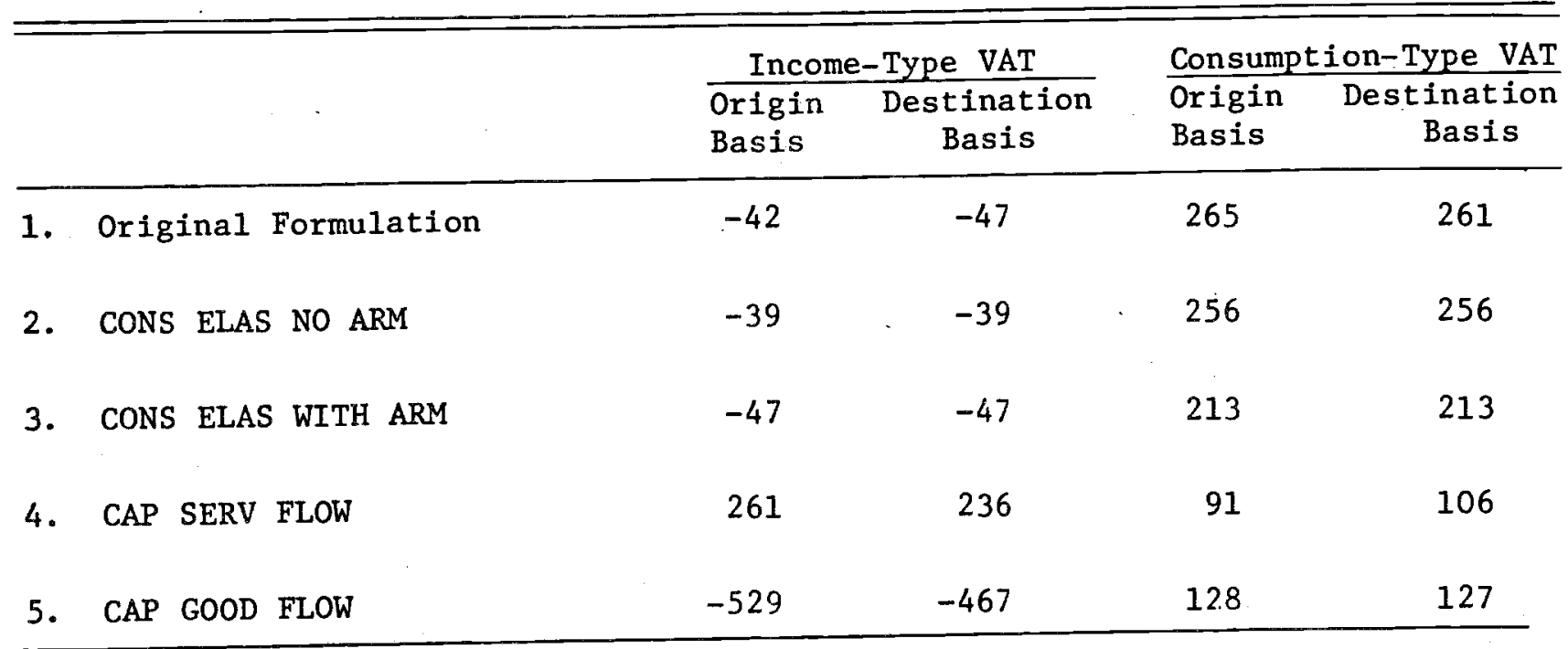

${ }_{\text {All }}$ results are central case results for runs involving six equilibria spaced ten years apart. An "additive" method of tax replacement (see page 34)
was employed in every case. Welfare effects are measured in billions of 1973 do11ars. 
is seen in some quarters in the U.S. as a trade-restricting measure since exports leave Europe tax free but imports are taxed as they enter. While this view is criticized by many academic economists who stress the neutrality of either tax base for a broadly based tax, it has nonetheless been influential in policy debate.

We model an origin based VAT as an equal rate factor tax on both primary factors and a destination based tax as an equal rate final sales tax on expenditures in the U.S. Under the income-type VAT all goods are taxed; under the consumption-type only current consumption goods. We model the latter feature through a savings deduction for the origin based VAT of the consumption type. We impose equal yield through an additive replacement in the income tax; income tax collections fall through a linear income tax reduction applied to all household income tax rates. These tax changes are thus regressive.

The VAT is constructed to be a non-distorting tax save for impacts on labor supply and savings. The introduction of this tax alternative therefore implies a scaling down of existing distorting taxes, which produces welfare gains. Consumption-type VAT gains are primarily due to the reduction in the intertemporal distortion of the income tax. In the consumption-type runs the VAT compounds multiplicatively with other taxes and neutrality between origin and destination bases holds exactly for the Armington and capital service flow cases and nearly so for the other cases.

The welfare gains in the income-type VAT runs are generally smaller than in the corresponding consumption-type VAT runs. The gains are smaller because the income-type VAT inefficiently distorts individuals' consumptionsavings decisions more than the consumption-type VAT, since the former tax applies to investment goods (as well as consumption goods) and in effect taxes 
savings. There is one exception to this general result: in the capital service flow case, the gains under an income-type VAT are larger than under the consumption-type. The domestic rental price of capital eventually rises (relative to the foreign rental price) under the income-type VAT but falls (relative to the foreign price) under the consumption-type VAT. As a result, capital is rented to the U.S. under the former tax and from the U.S. under the latter, in the capital service flow formulation. Since, as discussed earlier, those offering capital overseas receive only the net-of-tax price of capital as compensation, the direction of the capital service flow is favorable to the U.S. under the income-type VAT, and unfavorable to the U.S. under the consumption-type VAT. The favorable effect under the income-type tax more than compensates for any adverse impact related to the tax's distortion of consumptionsaving decisions.

The policy prescriptions from these runs are that foreign trade concerns regarding destination vs. origin based taxes do not provide a legitimate reason for the U.S. to introduce a VAT, but a broadly based VAT which replaces existing distorting taxes may be an efficiency gaining tax change.

\section{Conclusion}

In this paper we have described four alternative external sector formulations which can be used to represent external sector behavior in the FullertonShoven-Whalley tax model for the U.S. Our motivations are twofold: to assess the impact of alternative formulations on model findings, and to provide an enhanced capability for analysis of tax policies (such as a VAT) which connect closely with foreign trade issues. We consider two formulations of merchandise trade behavior using constant elasticity excess demand functions for foreigners' 
behavior. We also consider internationally mobile capital services and capital goods.

Under these different formulations, we reinvestigate two policy alternatives considered earlier by Fullerton et al $(1979,1980)$ : an 80 percent savings deduction in the income tax, and personal and corporate tax integration. We also examine the effects of introducing a ten percent value-added tax of the income type or consumption type, on either an origin or a destination basis.

Results indicate that the different external sector formulations can substantially affect the model's findings. The allowance for capital service flows can either greatly increase the efficiency gain of a tax policy (as in the case of corporate tax integration) or turn a significant gain into a large loss (as in moving to a consumption tax). Each of the policies which we investigated appears to have the potential to generate substantial capital service flows between the U.S. and abroad. When the net flow is from the U.S. to foreigners, the U.S. is adversely affected since those offering capital receive only the net-of-tax rental price. The specification of merchandise and service trade appears to affect our results far less than the capital flows modelling. This paper indicates that the evaluation of domestic tax policy is very sensitive to the functioning of international capital markets. Therefore, further research which reveals more precisely the operation of these markets would be most useful for future analyses. 
REFERENCES

Armington, P. S. (1969). "A Theory of Demand for Products Distinguished by Place of Production," I.M.F. Staff Paper8, PP. 159-176.

Boadway, R. and J. M. Treddenlck (1978). "A General Equilibrium Computation of the Effects of the Canadian Tariff Structure," Canadian Journal of Economics, August, Pp. 424-446.

Caddy, V. (1976), "Empirical Estimation of the Elasticity of Substitution;

A Review," Preliminary Working Paper OP-09, IMPACT Project,

Industrial Assistance Commision, Melbourne, Australia, November.

Deardorff, A. and R. M. Stern (1979). "An Economic Analysis of the Effects of the Tokyo Round of Multilateral Trade Negotiations on the United States and the Other Major Inudstrialized Countries," MrN Studies No. 5, prepared for Subcommittee on International Trade, Commttee on Finance, U.S. Senate, 96th Congress, Washington, D.C.

Feldstein, M. and C. Horloka (1980). "Domestic Savings and International Capital Flows," Economic Journal (forthcoming). .

Fullerton, D. (1980). "Transition Losses of Partially Mobile Industry Specific Capital," N.B.E.R. Working Paper, No. 520.

Fullerton, Don, A. Thomas King, John B. Shoven, and John Whalley (1980). "Tax Integration in the U.S.: A General Equilibrium Approach," Cambridge, Mass.: National Bureau of Economic Research Working Paper, No. 337R.

Fullerton, Don, John B. Shoven, and John Whalley (1978). "General Equilibrium Analysis of U.S. Taxation Policy," 1978 Compendium of Tax Research, Washington, D.C.: Office of Tax Analysis, U.S. Treasury Department. 
Fullertion, D., J. B. Shoven, and J. Whalley (1980). "Dynamlc General Equilibrium Impacts of Replacing the U.S. Income Tax with a Progressive Consumption Ta: ," paper presented at N.B.E.R. Tax Conference on Taxation of Capital, November 16-17, 1979.

Gorman, W. M. (1957). "Tariffs, Retaliation, and the Elasticity of Demand for Imports," Review of Economic Studies, Vol..XXV, pp. 133-62.

Johns on, H. G. (1953). "Optimum Tariffs and Retaliation," Review of Economic Studies. Vol. XXI, Pp. 142-153. Reprinted with amendments in H. G. Johnson International Trade and Economic Growth [George Allen and Unwin, 1961]. Harberger, A. C. (1980). "Vignettes on the World Capital Market," American Economic Review, May.

Merril1, O. H. (1971). "Applications and Extensions of an Algorithm that Computes Fixed Points of Certain Upper Semi-Continuous Mappings," unpublished Ph.D. Thesis, University of Michigan.

Scarf, Herbert E., with the collaboration of Terje Hansen (1973). The Computation of Economic Equilibria [New Haven, Conn.: Yale University Press].

Stern, R. M., J. Francis, and B. Schumacher (1977). Price Elasticities in International Trade: An Annotated Bibliography [Macmillan Publishers for the Trade Pollcy Research Center].

Whalley, J. (1980). "Discriminatory Features of Domestic Factor Tax Systems in a Goods Mobile, Factors Immobile Trade Model: An Empirical General Equilibrium Approach," Journal of Political Economy (forthcoming).

Whalley, J. and B. Yeung (1980). "External Sector 'Closing' Rules in Applied General Equilibrium Models," University of Western Ontario, mimeo, April. 